\title{
Theories of Haitian Mobility and their Relationship to the Dominican Sugar Industry Juliana Ramirez
}

Juliana Ramirez is a fourth-year student and a Jackman Humanities Institute Undergraduate Fellow doing a specialist in Art History and a minor in Spanish. She is interested in the representation of the 'Other' in Western art during the two centuries following the encounter between Western Europe and the Americas. More specifically, in how depictions of 'racial' differences in Renaissance paintings and prints helped to shape European identity. Geographically, her research focuses on Mexico, the Caribbean, the Netherlands, Portugal and Spain.

In this paper I will study the emergence and evolution of the Dominican sugar plantations-and their employment of migrant labor-in order to delineate the reasons that led to Haitian migration to the Dominican Republic. Firstly, I will investigate different scholarly explanations on migration in the Caribbean; secondly, I will describe how the Dominican ingenio evolved; and finally, I will compare the migration theories with the economic development of the Dominican sugar industry in order to discern the possible causes of Haitian migration to the Dominican Republic during the early Twentieth century.

Many different scholars explain the reasons why Haitians migrate. Glenn Perusek, for instance, believes that "it is Haiti's position as the most backward country in the Western hemisphere that leads to immutable outflow from the country." ${ }^{1}$ In other words, Haiti, and its situation of extreme poverty, pushes its citizens out of the country. Perusek takes this argument so far as to claim that the situation in Haiti is so dire that the frequency of Haitian migration is unaffected by labor demand. ${ }^{2}$ According to Perusek, for Haitians, migration is a choice of life or death: "migrate or starve." 3

Other scholars, however, assume less radical positions. Andrés Cortén and Michiel Baud, for example, believe that what

1 Glenn Perusek, "Haitian Emigration in the Early Twentieth Century," International Migration Review 18, no. 1 (Spring, 1984): 6.

2 "The reason changes in labor demand in receiving countries play little or no part in determining the level of migration from Haiti-once migration flows are established-stems from the fact that the situation for most Haitians at home is not 'normal'. The situation-absolute poverty-is the fundamental cause of migration from Haiti." Ibid, 7.

$3 \mathrm{lbid}, 14$. 
impels Haitians to migrate is the possibility of "monetary savings." 4 Cortén argues that because of "the succession regime [in Haiti, which led] to the parceling of land," 5 the Haitian economy remained 'backward' and devoted to small agricultural production. ${ }^{6}$ Mercantilism, then, could not-and did not-emerge in Haiti; instead, the majority of financial transactions were conducted through systems of exchange and bartering.7 In other words, the cause of Haitian emigration, according to Cortén and Baud, is not Haiti's extreme poverty, but the desire to save hard currency to bring (or send) back home in order to buy consumer goods without having to exchange the food that they grow. ${ }^{8}$

Dennis Conway takes on a more historical approach. He argues that people from the Caribbean see "mobility options...as an appropriate response to their situations" because "their predecessors had emigrated away from the plantations." 9 Put differently, migration in the Caribbean emerges as a historical strategy to ameliorate one's situation. Samuel Martínez, elaborates on this idea and argues that "given the Caribbean region's long history of forced immigration and bonded labor, it is not surprising that geographical mobility was one of the first ways that Afro-Caribbean peoples asserted their freedom after emancipation."10 Migration, from this viewpoint, is not simply a necessity but also a choice.

Martínez, furthermore, comments that when larger migrations occur there usually is an "active inducement by government or host employers,"11 and therefore, in the case of mass migrations, the individual's desire to 'escape poverty' or improve

\footnotetext{
4 Michiel Baud, "Sugar and Unfree Labour: Reflections on Labour Control in the Dominican Republic, 1870-1935," Journal of Peasant Studies 19, no. 2 (1992): 312. And, Andrés Cortén et al, "Haití: estructura agraria y migración de trabajadores a los centrales azucareros dominicanos", in Azúcar y política en la República Dominicana (Santo Domingo: Ediciones de Taller, 1976), 106.

5 "La tenencia de la tierra es aquella de la pequeña propiedad que da lugar, en razón del régimen sucesorio, al parcelamiento" [All translations from Spanish to English are mine]. Cortén et al, 102.

6 Franc Báez Evertsz, Braceros haitianos en la República Dominicana (Santo Domingo: Ediciones de Taller, 1984), 40.

${ }^{7}$ Corte et al, 100.

8 Ibid.

9 Dennis Conway, "Caribbean International Mobility Traditions," Boletín de Estudios Latinoamericanos y del Caribe 46 (June, 1989): 22.

10 Samuel Martínez, "From Hidden Hand to heavy Hand: Sugar, the State, and Migrant labor in Haiti and the Dominican Republic," Latin American Research Review 34, no. 1 (1999): 60.

$11 \mathrm{lbid}, 59$.
} 
their situation is less significant than the migration programs promoted by governments or employers.

Frans Báez Evertsz agrees with Martínez, and argues that "Haitian citizens emigrate because of extreme poverty and unemployment [but also] because in [the receiving] country there are: a constant demand for labour, and a recruiting system that stimulates, facilitates, and regulates the incorporation of Haitian workers into the host country." 12 In other words, both the receiving and sending government must cooperate in the sponsorship of migrants.

Of these theories concerning migration in the Caribbean, which one best explains the mass migration of Haitians to the Dominican Republic in the early twentieth century? Since most of these migrants work in the sugar plantations, an analysis of the development of the ingenios will be necessary to answer this question.

The Dominican Republic was the last Caribbean country to develop large-scale sugar production. ${ }^{13}$ Nonetheless, Dominican sugar production emerged and one could argue, at the opportune moment. Its development in 1870 coincides with "the outbreak of the first Cuban war of independence (1868-78)...[that] affected the production of the world's major producer-exporter [of cane sugar, and] the war between France and Germany in 1870...[that] affected the major producers of beet sugar [in Europe]."14

The Dominican Republic, however, did not replace Germany or Cuba as the world's major producer of sugar. As a matter of fact, many years passed before the incipient Dominican plantations transformed into large, modern, profitable ingenios. Del Castillo describes this process in three phases: (1) the competitive phase

\footnotetext{
12 "Los ciudadanos haitianos emigran de su país debido a los altos niveles de pobreza y desocupación imperantes; y se dirigen a [otro país] porque existe en este país una oferta predeterminada de empleos para ellos y un sistema de reclutamiento que estimula, regula y facilita su incorporación”. Báez Evertsz, 121.

13 Harmannus Hoetink, “Labour 'Scarcity' and Immigration in the Dominican Republic c.1875-c.1930," in Labour in the Caribbean, ed. Malcolm Cross and Gad Heuman (London: Macmillan Publishers Ltd, 1988), 160.

14 José del Castillo, "The Formation of the Dominican Sugar Industry: From Competition to Monopoly, from National Semiproletariat to Foreign Proletariat," in Between Slavery and Free Labor: The Spanish-Speaking Caribbean in the Nineteenth Century, ed. Manuel Moreno Fraginals, Frank Moya Pons, and Stanley L. Engerman (Baltimore: The Johns Hopkins University Press, 1985), 215.
} 
(early 1870 - 1884 crisis), (2) the transition phase (1884 crisis-US occupation), and (3) the phase of importation of Haitian labor (US occupation-1920s crisis). ${ }^{15}$ These three moments will help us understand the evolution of the plantations, and the reasons why the importation of Haitian labour became imperative in this process.

The competitive phase "was characterized by the predominance of individual businesses, a semi-mechanized technology, a predominantly national (Dominican) labor force, and the existence of attractive salary levels." 16 However, with the crisis of $1884,{ }^{17}$ prices plummeted, and producers "were forced to cut their expenditure." 18 Dominican workers refused to perform the same job for less money, and since they had other sources of income, as the terrenos comuneros, ${ }^{19}$ they simply abandoned the plantations and returned to their communal lands. Both the government and planters proved unable to control local labour because most workers had access to land through which they could earn a living. ${ }^{20}$ Dominican workers, in other words, did not need wage labour to survive; they had other options.

In the transition phase the main objective was the economic recovery of the industry, and thus the "concentration of capital." 21 Since Dominican workers were not willing to work in the plantations for the wages offered, a need for foreign labour emerged.22 This need was first satisfied by cocolos, West Indian workers coming from British territories. ${ }^{23}$ As Patrick E. Bryan points out, "it was not the

\footnotetext{
15 Ibid, 217-220.

$16 \mathrm{Ibid}, 217$.

17 "The beet industry had undergone extraordinary technological development during the second half of the Nineteenth century...In this regard the sugar cane industry had been lagging. The gap reached such proportions that for world sugar production in the 1899-1900 harvest...31 percent was cane sugar and 69 percent was beet." Ibid., 224.

18 Baud, 309.

19 Hoetink, 166.

20 "The durable 'scarcity' of local labour for the sugar sector may be attributed to a mixture, varying over time, of such factors as low population density in combination with easy access to land." Ibid., 169. And "The Dominican Republic's sparse population and easy availability of land caused the country to resemble an open frontier in 1875 ...If left free, rural Dominicans could easily earn a living as independent agricultural producers without needing to sell their labor to large proprietors." Martínez, 62.

21 Del Castillo, 217.

22 "By the 1910s, Dominicans had mostly abandoned labor in the cane fields to immigrant workers." Martínez, 65.

${ }^{23}$ Del Castillo, 238-242.
} 
welfare of labour that mattered, or the color of the labour, but the maximization of profit," 24 and cocolos worked for far less money than Dominicans: they were "a source of cheap labor [and] could be subjected to harsh discipline with less hesitation than Dominican national.”25 Because West Indians did not speak Spanish, and did not have strong community ties in the Dominican Republic they lacked the power to organize effectively. ${ }^{26}$

However, there was a paradox. While planters encouraged the importation of foreign labor "in 1912, the Dominican government passed a law that declared in part that "natives of European colonies in America, those of Asia or Africa and of Oceania, as also laborers of any race except the Caucasian, need prior permission to immigrate into the country." 27 In other words, the Dominican government became stricter on its migration policies, and outright favoured the migration of whites. It was a racist policy that allowed sugar planters to import and exploit foreign, non-white labor: these non-white migrants were not welcomed in the Dominican Republic, and thus, working on the plantations became their only key to immigrate into the Dominican. Planters, in other words, saw an effective solution to lower wages (and thus optimize profit) in the implementation of foreign non-white labour, for these workers were more vulnerable.

Furthermore, the Dominican government was "financially weaker than some of the sugar companies," ${ }^{28}$ and "import/export taxes were [the government's] only source of income." 29 Therefore, sugar planters exerted a lot of power on the government's policy making. What ensued from this power dynamic was a "process of 'illegalisation' of [the] labor force." 30 Put differently, planters took advantage of the racist "national rhetoric [which] provided [them] with a lever to increase their exploitation of...workers." ${ }^{11}$ With the illegalization of non-white labour, planters had more power over

\footnotetext{
24 Patrick E. Bryan, "The question of Labor in the Sugar Industry of the Dominican Republic in the Late Nineteenth and Early Twentieth Centuries," in Between Slavery and Free Labor: The Spanish-Speaking Caribbean in the Nineteenth Century, ed. Manuel Moreno Fraginals, Frank Moya Pons, and Stanley L. Engerman (Baltimore: The Johns Hopkins University Press, 1985), 238.

25 Martínez, 65.

26 Ibid.

27 Bryan, 242.

28 Martínez, 69.

29 Baud, 311.

30 Ibid, 314

$31 \mathrm{lbid}$.
} 
their employees: planters, who financed the Dominican government through their payment of import/export taxes, also allowed for illegal non-white labour to migrate to the Dominican Republic to work in the plantations. These workers, however, could not exit the plantation, for they were illegal in the country. Planters had manipulated the government's policy in order to make their workers more vulnerable and exploitable.

Furthermore, in 1916, when the US occupied the Dominican Republic, "a Land Registration Law was promulgated which effectively put an end to the terrenos comuneros." 32 As Báez Evertsz mentions, "the installation of foreign agricultural companies granted with huge land concessions, was one of the most direct and important mechanisms for the dismantlement of the traditional agricultural system [in the Dominican Republic]." 33 This reorganization of land, consequently, led to the conversion of sugar plantations into "well-protected bastions of (foreign) capital with practical sovereignty on their premises," 34 in which sugar planters had absolute control over workers. 35

Haitian immigration to the Dominican Republic emergesas a major phenomenon-during the period of the U.S. occupation. ${ }^{36}$ Firstly, in the 1920 S West Indians were finding other job possibilities in Curaçao and Aruba;37 and secondly, the Haitian U.S. occupation coincides with the Dominican U.S. occupation: "the U.S. military governments of Haiti (1915-1934) and the Dominican Republic (1916-1924) began to set up conditions for the state to take an increasingly active hand in bracero recruitment and resettlement." 38 As Hoetink comments, efforts to regulate immigration "were...never

\footnotetext{
32 Hoetink, 169.

33 "La instalación de empresas agrícolas extranjeras, concesionarias de amplias porciones de tierra, fue uno de los principales y más directos mecanismos de desestructuración del sistema agrícola tradicional”. Báez Evertsz, 42.

34 Baud, 311.

35 One of the most evident forms of control over workers is the fact that "Dominican sugar companies minted their own money, which could only be used on the plantation...Employees of the plantation were obliged to buy their daily necessities in the bodegas of the company, where prices were invariably higher than in other stores. [Furthermore] as long as [employees] did not have official 'Dominican' money they were prevented from leaving the plantation. The companies were often prepared to exchange the vales only at the end of the harvest to retain maximum control of their labourers." Baud, 313-14.

36 Perusek, 12; Hoetink, 173.

37 Bryan, 245.

38 Martínez, 67.
} 
at variance with the interests of the large sugar estates, by now [1920s] mostly US owned." 39 In other words, Haitian mass migration to the Dominican Republic emerges during the U.S. military occupations, for both government and employers (both under the control of the U.S.) deliberately create the conditions for the mobility of labour. 40

Of all the theories on migration in the Caribbean explained at the outset of this paper, Martínez's theory best represents the relationship between the Dominican sugar plantations and Haitian mobility. Albeit the extreme levels of poverty and Haiti's weak economy, the cause of Haitian migration to the Dominican Republic need to be understood not only as a personal decision of the migrant, but also as a system implemented by governments and entrepreneurs to exert control over workers and to lower wages. In fact, according to Martínez, "for a time, emigration fees and recruiting permits became the Haitian government's largest internal source of revenue." ${ }^{41}$ Thus, migration is profitable, not only for the receiver country in the form of cheap labour, but also for the sender country in the form of permits and fees (and, of course, in the avoidance of social policy reform by the displacement of people that were likely to demand reform had they stayed). Moreover, the creation of anti-migratory laws should be understood as a way to racially "isolate [the] labor force [in order] to maintain strict control over it." 42

The paradox is then unraveled: in spite of its apparent contradiction, migratory laws, as Hoetink argues, are never opposed to entrepreneurs' interests. The fact that mass Haitian migration occurred at the same time as the U.S. occupation-in which U.S. interests infiltrated both government and host employersdemonstrates how an "active inducement" 43 by governing bodies, more powerful than the individual interest, induced mass Haitian migration to the Dominican Republic in the early Twentieth century to be used as a source of cheap and pliable labour.

\footnotetext{
39 Hoetink, 172.

40 Martínez, 59.

$41 \mathrm{lbid}, 68$.

42 Baud, 302.

43 Martínez, 59.
} 


\section{Works Cited}

Báez Evertsz, Franc. Braceros haitianos en la República Dominicana. Santo Domingo: Ediciones de Taller, 1984.

Baud, Michiel. "Sugar and Unfree labour: Reflections on Labour Control in the Dominican Republic, 1870-1935." Journal of Peasant Studies 19, no.2 (1992): 301-325.

Bryan, Patrick E. "The Question of Labor in the Sugar Industry of the Dominican Republic in the Late Nineteenth and Early Twentieth Centuries." In Between Slavery and Free Labour: The Spanish-Speaking Caribbean in the Nineteenth Century, edited by Manuel Moreno Fraginals, Frank Moya Pons, and Stanley L. Engerman, 235-251. Baltimore: The Johns Hopkins University Press, 1985.

Conway, Dennis. "Caribbean International Mobility Traditions." Boletín de Estudios Latinoamericanos y del Caribe 46 (June, 1989): 17-47.

Cortén, Andrés, Carlos Ma. Vilas, Mercedes Acosta, and Isis Duarte. "Haití: estructura agraria y migración de trabajadores a los centrales azucareros dominicanos." In Azúcar y política en la República Dominicana, 87-114. Santo Domingo: Ediciones de Taller, 1976.

Del Castillo, José. "The Formation of the Dominican Sugar Industry: from Competition to Monopoly, from National Semiproletariat to Foreign Proletariat." In Between Slavery and Free Labour: The Spanish-Speaking Caribbean in the Nineteenth Century, edited by Manuel Moreno Fraginals, Frank Moya Pons, and Stanley L. Engerman, 215-234. Baltimore: The Johns Hopkins University Press, 1985.

Gorden, Michelle E. "Haitian Forced Labor in the Dominican Republic." Comparative labor Law and Policy Journal 15 (January, 1994): 206-249.

Hoetink, Harmannus. "Labour 'Scarcity' and immigration in the Dominican Republic c.1875-c.1930." In Labour in the Caribbean, edited by Malcolm Cross and Gad Heuman, 160-175. London: Macmillan Publishers Ltd., 1988.

Martínez, Samuel. "From Hidden Hand to Heavy Hand: Sugar, the State, and Migrant Labor in Haiti and the Dominican Republic." Latin American Research Review 34, no. 1 (1999): 57-84.

Perusek, Glenn. "Haitian Emigration in the Early Twentieth Century." International Migration Review 18, no.1 (Spring, 1984): 4-18. 